\title{
EFL Students' perceptions on Gender Stereotypes through their narratives ${ }^{1}$
}

Percepciones de Estudiantes de Inglés como Lengua Extranjera sobre Estereotipos de Género a ravés de sus Narrativas

\section{Jhonatan Vásquez-Guarnizo, Maribel Chía-Ríos and Mairon Felipe Tobar-Gómez ${ }^{2 *}$}

Universidad Pedagógica y Tecnológica de Colombia, Universidad de La Salle, Colombia

${ }^{1}$ Received: February 6th 202 / Accepted: September 11th 2020

2 jhonatan.vasquez@uptc.edu.co; maribel.chia@uptc.edu.co; mtobar66@unisalle.edu.co 


\section{Abstract}

This research study was conducted with twelve students from the Modern/Foreign Languages program at Universidad Pedagógica y Tecnológica de Colombia. It was aimed at unveiling EFL students' perceptions on Gender Stereotypes through their narratives in three different moments. Focus group interviews, field notes, and students' artifacts were used as data collection instruments. Data was analyzed under an interactional analysis proposed by Riessman (2005). Findings showed that students' lived experiences on this issue have permeated over the time the way they see their present and future; and their perceptions on gender stereotypes differ from their past generations as they consider themselves as a new generation who does not see any distinction among genders.

Key words: artwork; gender stereotypes; students' perceptions; EFL; experiences

\section{Resumen}

Este estudio de investigación se realizó con doce estudiantes del programa de Lenguas Modernas / Extranjeras en la Universidad Pedagógica y Tecnológica de Colombia. Su objetivo era revelar las percepciones de los estudiantes de inglés como lengua extranjera sobre los estereotipos de género a través de sus narraciones en tres momentos diferentes. Se utilizaron entrevistas de grupos focales, notas de campo y artefactos por parte de los estudiantes como instrumentos de recolección de datos. Los datos fueron analizados bajo un análisis de interacción propuesto por Riessman (2005). Los resultados mostraron que las experiencias vividas por los estudiantes sobre este tema han permeado con el tiempo la forma en que ven su presente y futuro; y sus percepciones sobre los estereotipos de género difieren de sus generaciones pasadas ya que ellos se consideran como una nueva generación que no ve ninguna distinción entre géneros.

Palabras clave: obras de arte; estereotipos de género; percepciones de los estudiantes; inglés como lengua extranjera; experiencias

\section{Resumo}

Este estudo de pesquisa foi realizado com doze estudantes do programa de Línguas Modernas / Estrangeiras na Universidade Pedagógica e Tecnológica da Colômbia. Seu objetivo era revelar as percepções dos estudantes de inglês como língua estrangeira sobre os estereótipos de gênero através das suas narrações em três momentos diferentes. Utilizaram-se entrevistas de grupos focais, notas de campo e artefatos por parte dos estudantes como instrumentos de coleta de dados. Os dados foram analisados sob uma análise de interação proposta por Riessman (2005). Os resultados mostraram que as experiências vividas pelos estudantes sobre este tema permearam com o tempo a forma em que veem seu presente e futuro; e suas percepções sobre os estereótipos de gênero diferem das suas gerações passadas, já que eles se consideram como uma nova geração que não vê nenhuma distinção entre gêneros.

Palavras chave: obras de arte, estereótipos de gênero, percepções dos estudante; Inglês como uma língua estrangeira; experiências 


\section{Introduction}

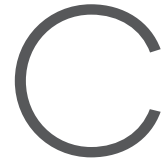

urrently, many young people's perceptions are influenced by an abundance of social media messages which have a strong effect when creating a variety of misconceptions that build certain rigid thoughts about the differences between genders. According to Barrera and Cantor (2007), "the use of stereotypes is a part of our everyday way of thinking; for this reason, our society often innocently creates and perpetuates stereotypes" (p. 163). Unfortunately, this process has been shaping students' minds without having a thought about it; that is why, gender stereotypes exist in home, schools, and workplace (Ifegbesan, 2010).

In Colombia, some studies (Castañeda, 2012; Castañeda-Peña, 2008a, 2008b, 2009, 2010; Durán, 2006; Rojas, 2012) have researched deeply into the importance of gender in foreign language contexts. However, EFL Student's perceptions on Gender Stereotypes have not been researched enough currently. In that sense, a gender stereotype is viewed as one type of subjective perception of what a man or woman should be or how people should behave (Martin \& Halverson, 1981). They portray the male as the strong and dominant person who works outside the home in oftenprestigious occupations, while the female is usually portrayed as being subordinate and confined to the home (Fiske, 1993; Stangor \& Lange, 1994).

The world is evolving every day and students are not being left behind; their perceptions are changing, as well as their thoughts about living in the way their past generations once did. In such a way, students have become more aware of having a different perception in their lives and how they see their future.

Thus, for this research study, we proposed the following research question:

What do EFL Students' narratives reveal about gender stereotypes when being exposed to a film, before/now photographs, and their own artwork?

\section{Theoretical Framework}

\section{The role of films, photographs, and artwork.}

The need to motivate students in the EFL classroom has become an established area of research and discussion (Gardner, 1985). In that sense, using English speaking foreign films within EFL classrooms provides students with an excellent source of native dialogue, cultural context, and interesting material (Brown, 2010). 
In this regard, Aguirre and Ramos (2011) argue that films can be used as a "powerful tool to explore educational aspects such as gender, social roles, and power relationships" (p. 175). Therefore, watching films in the classroom can help students discover the possibility that they can be whatever they want to be, no matter what others may think about them (Corral, 2014).

In this manner, incorporating films into the EFL classroom means bringing language to life (Schander, Balma \& Massa, 2013). Furthermore, based on Schander, Balma and Massa (2013), interpreting visual art can be an excellent way to teach productive skills and build a lexicon. Thus, photographs were brought into the classrooms as a valuable teaching resource that teachers and learners in more meaningful and memorable learning experiences.

Art has always been an effective tool for teaching and learning among various classes of people (Masoumeh \& Masoud, 2011). Freedman (2003) confirms that it is key to teach visual culture, so they are able to view the visual arts by understanding their meanings, purposes, relationships, and influences. Based on Peñaloza and VásquezGuarnizo (2019), "the benefits of utilizing artwork in the classroom are countless" (p. 133). Therefore, through artwork, students can be challenged to think critically and analytically (Barber, 2015) and could promote the "inclusion of different perspectives" (Schäffler, 2018, p. 45).

\section{Gender stereotypes.}

From a postmodern perspective, and acknowledging the contributions of scholars such as Butler (1990) and Foucault (1992), gender is understood as a sociocultural category by which the issue of the body is connected to everyday social and cultural practices and discourses (Mojica \& Castañeda-Peña, 2017, p. 142). In this sense, gender refers to the social differences between men and women, establishing stereotypes boys and girls suffer from birth. Therefore, it has nothing to do with the biological and physical characteristics each sex has, but with the functions, values, and responsibilities they play in society (Corral, 2014, p. 6).

Gender stereotypes are present everywhere in every feature of society, such as: work, family, daily vocabulary, advertisements, and television. They are transmitted from father to son through generations, affecting the development of a free society (Corral, 2014). According to Six and Eckes (1991), gender stereotypes are defined as "products of normal everyday cognitive processes of social categorization, social inference and social judgement" (p. 58). Therefore, Corral (2014) affirms that some gender stereotypes which society has taught us are "Boys dress in blue and girls in pink. Boys study science and technology, and girls languages and literature. Men fight and women cry. Men earn money and women take care of the house and the family" (pp. 6-7). 
In this regard, Barrera and Cantor (2007) affirm that "the use of stereotypes is a part of our everyday way of thinking; for this reason, our society often innocently creates and perpetuates stereotypes" (p. 164). Hence, since gender stereotyping in education perpetuates the existing inequality between males and females, the elimination of gender stereotyped messages is vital (Şeker \& Dinçer, 2014), as they help determining ideas and values that children come to accept as norms (Haque \& Chandran, 2004).

\section{Students' perceptions.}

There has been a recent focus on understanding students' perceptions on Education. Wright (2004) states that perceptions vary from person to person and consequently, different people perceive different things about the same situation. Therefore, we assign different meanings to what we perceive and the meanings we give to a situation might change for a certain person who does not see it as we do. Based on Eagly and Karau (2002), there is a big difference between men's and women's perceptions regarding leadership; therefore, males tend to show a stronger tendency than females since they view women as less qualified for such activity.

In this manner, the way students pay attention to a certain situation, experience and/or action might reflect the way they view the world and it can influence the way they determine what to process or believe in. The perception of a specific situation is a personal interpretation of information from each human being's own reality. That is why they perceive what they see, they think what they feel or they talk about what they know as their perceptions differ from one experience to another since each human being's interaction will never be the same in each mind.

\section{Methodology}

For the purpose of this research study, a qualitative approach was used as this one seeks to understand the construction of a reality built by participants (Richards, 2000, p. 148), and it is more concerned with "understanding individual's perceptions of the world since it looks for insights rather than a statistical analysis" (Bell, 1993, p. 6). Moreover, we utilized narrative inquiry where storytelling became "a powerful tool to make sense of the world, to attribute meaning to experiences participants have lived" (Torres-Cepeda \& Ramos-Holguín, 2019, p. 14).

Based on Gadamer (2002), "it is not the word what we can see: it is the universe what we try to comprehend" (p. 68). Therefore, we focused not only on participants' 
lived experiences, but also on the meaning they gave to those experiences (Trahar, 2006), since understanding their lived experiences from a narrative perspective implies connecting feelings, past-present professional-personal events, and possible future implications of those events in order to gain insights into the way participants co-construct their own self (Coulter, Michael \& Poynor, 2007).

\section{Context and Participants}

This research study took place at a public university in Colombia with a group of twelve students whose ages range from nineteen to thirty-seven. This group of participants was composed of 8 female and 4 male EFL students. In addition, this research study was carried out in the English Workshop II course, ascribed to the Foreign Languages Program in sixth semester. In this same vein, this course aims at improving students' writing production at the same time they interact and communicate to others in English. Nonetheless, this specific course has a diverse population as it receives students who have failed the English Written Production course in the Modern Languages Program in third semester.

This population was chosen as a notorious preference to be grouped by genders was evident. At the beginning of each class, there were female groups on one side and male groups on the other one, which made us reflect upon this issue, having in mind they will be future language teachers. We thought that issue was a perfect opportunity to raise awareness and eradicate any form of gender stereotyping they will face once they teach.

Thereby, in this research study, half of the participants belonged to the Foreign Languages Program whose students study to become English and/or French teachers at elementary schools. The other half of them belonged to the Modern Languages Program, whose students study to become high school Spanish and/or English teachers.

For this particular case, participants voluntarily accepted to be part of this research study by means of signing a consent form (Annex 1) where all of them opted to choose a pseudonym as Table 1 shows. Additionally, all of them were able to communicate their ideas in English; however, they preferred to speak in Spanish when telling their lived experiences and those narratives were translated to English for the purpose of this research study. 
Table 1. Participants' information.

\begin{tabular}{|c|c|c|c|}
\hline $\begin{array}{c}\text { Participants' } \\
\text { pseudonyms }\end{array}$ & $\begin{array}{c}\text { B.A } \\
\text { Program }\end{array}$ & Gender & Age \\
\hline Carolina & \multirow{6}{*}{$\begin{array}{l}\text { Foreign } \\
\text { Languages } \\
\text { Program }\end{array}$} & Female & 20 \\
\hline Luciana & & Female & 19 \\
\hline Andrea & & Female & 20 \\
\hline Jenniwell & & Female & 29 \\
\hline Ariadna & & Female & 19 \\
\hline Cris & & Male & 37 \\
\hline Saluifer & \multirow{6}{*}{$\begin{array}{l}\text { Modern } \\
\text { Languages } \\
\text { Program }\end{array}$} & Female & 22 \\
\hline M.F & & Female & 21 \\
\hline Machaela & & Female & 23 \\
\hline Daniel & & Male & 21 \\
\hline Andrés & & Male & 28 \\
\hline Manuel P & & Male & 25 \\
\hline
\end{tabular}

In this sense, this study was carried out in three different moments. The first moment was divided into four-session classes. In the first two-session class, students were exposed to a film titled "On the basis of sex" which shows the struggle a female character faced with discrimination against women when fighting to have the same rights as men in the United States. As each two-session class is two hours long, the second two-session class from the first moment was at a different time. During this moment, students had a space for a focus group in which they expressed their thoughts on the film and how they are related to this issue currently.

Furthermore, in the second moment, visual art was included through some before/ now photographs which revealed how women have been underestimated for years due to their gender and how they are positioned nowadays. These photographs were placed on the walls around the classroom so they could simulate being at an art gallery where they were able to contrast this issue as viewers. Once students finished walking around the classroom, their points of view were heard though a focus group interview.

Lastly, in the third moment, students were asked to draw their own artwork which expressed the way they saw men/women in their contexts. When they were done, all the drawings were pasted on the board and another focus group took place. This one was a key part of this study as it was our closing moment. It allowed these EFL students' perceptions to come up with more determination since they were able to show through a drawing what their perceptions actually were. Besides, as they had the 
chance to choose one which caught their attention the most, they were able to speak about their classmates' perceptions as well and how the drawing someone else drew was relevant for their future lives.

Table 2 illustrates how those three moments previously described were carried out by means of providing the dates, a brief description, and an image that represents each moment.

Table 2. Three moments of the development of the study

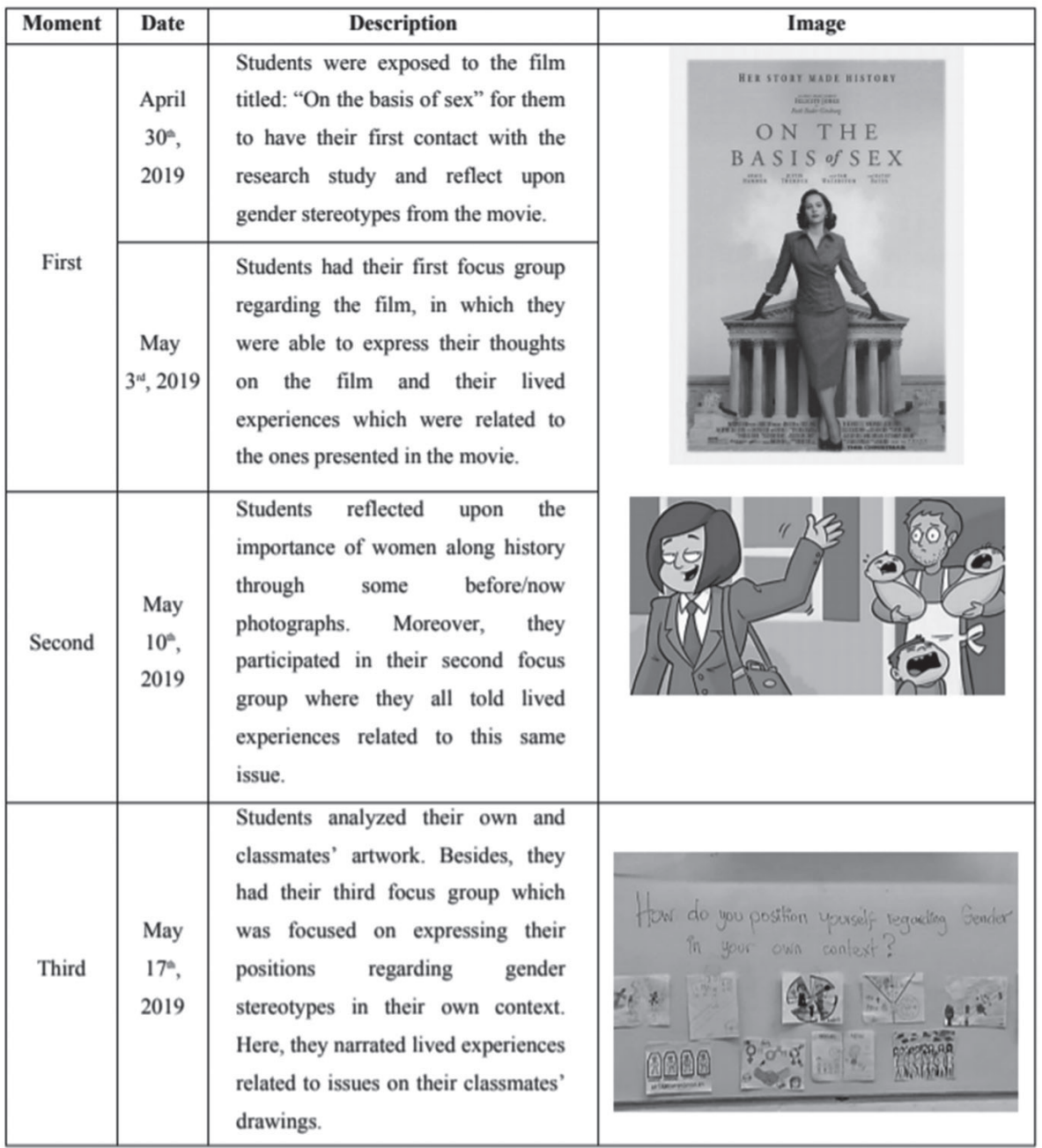




\section{Data Collection Tools}

Three focus group interviews, students' artifacts and field notes were the data collection tools applied in this research study. According to Rabiee (2004), focus group interviews provide information about ideas and feelings that individuals have about certain issues, as well as illuminating the differences in perspective between groups of individuals as focus group interviews gather a small group of people to explore attitudes and perceptions, feelings and ideas about a topic (Denscombe, 2007).

Secondly, students' artifacts were collected in the third moment through their own artwork. Based on Ormrod (2005), it is really useful to save samples of students' work produced over time since they can take the form of short stories, lab reports, class notes, handouts, quizzes, which provide equally viable connections to the real-world classroom context. In addition, Weber and Mitchell (1996) affirms that "drawings provide self-reflection by bringing to light ambivalences in teaching identities that might remain hidden" (p. 303). Therefore, when we draw, that artwork displays a hidden reality that helps individuals transmit a true-self context becoming drawing as a powerful means for them to express hidden messages.

Lastly, three field notes were applied throughout the development of this study. Based on Efron and Ravin (2013), field notes "are detailed descriptions of what you see, hear, and sense during the observation, and the thoughts, feelings and understandings these observations provoked" (p. 88). In that regard, the three video-recorded moments were transcribed since the video information needs to be transformed into written data "transcripts" to facilitate the analysis (Lankshear \& Knobel, 2004) which has to be carried out "as soon as possible after a lesson" (Hopkins, 2008, p. 116).

\section{Data Analysis and Findings}

Once participants' oral narratives were collected, they were transcribed and analyzed under an interactional analysis. Based on Riessman (2005), the emphasis is placed on the dialogic process between teller and listener in an interactional analysis. Stories of personal experience, organized around the life world of the teller, may be inserted into question and answer exchanges; therefore, participants' narratives about their lived experience are occasioned in particular settings were storyteller and questioner jointly participate in conversation (p. 4).

According to Torres-Cepeda and Ramos-Holguín (2019), "this research method helps to understand a narrative by means of splitting it into critical fractions which play a meaning-making role in the whole narrative" (p. 16) due to an interactional analysis is not only focused on the content of a text (thematic analysis), the way a story is told (structural analysis), but also on the co-construction process between teller and 
listener (interactional analysis). In this sense, this analysis is carried out step by step as one is connected to the other; that is why, we analyzed participants' narratives through a three-step analysis: thematic, structural, and interactional.

Firstly, participants' lived experiences were analyzed by focusing on the content of the story per se. Here, data is grouped into a similar thematic category, data is interpreted by means of focusing on what is said (Riessman, 2005, p. 3). Secondly, we paid attention to the way participants' lived experiences were told as "human beings are storying creatures that make sense of the world and the things that happen to them by constructing narratives to explain and interpret events both to themselves and to other people" (Sikes \& Gale, 2006, p. 1).

Lastly, we validated data by means of giving meaningful importance to the interaction, interpretation and sense/meaning making processes that were created among both parts, tellers (participants) and listeners (researchers). According to Bruner (1994), "a life is not how it was but how it is interpreted and reinterpreted, told and retold" (p. 36); therefore, by focusing on narrative, we are able to investigate not just how stories are structured and the ways in which they work, but also who produces them and by what means; how narratives are silenced or accepted and what, if any, effects they have (Andrews, Squire \& Tamboukou, 2013, p. 2).

In short, this three-step analysis: thematic, structural, and interactional gave us the chance to comprehend in-depth participants' lived experiences about gender stereotypes. We analyzed, interpreted, re-interpreted, constructed, and re-constructed participants' narratives in order to raise awareness about gender stereotyped messages and gain insights into the way participants co-construct their own self (Coulter, Michael \& Poynor, 2007).

In such way, three themes emerged from our interactional analysis (Riessman, 2005), which aim at answering our research question as it can be appreciated in Table 3.

Table 3. Main themes.

\begin{tabular}{r|c}
\hline RESEARCH QUESTION & MAIN THEME \\
\hline \multirow{3}{*}{$\begin{array}{c}\text { What do EFL Students' narratives reveal about gender stereotypes } \\
\text { when being exposed to a film, beforelnow photographs, and their } \\
\text { own artwork? }\end{array}$} & We are all equal \\
\cline { 2 - 2 } & Changing roles \\
\hline
\end{tabular}




\section{We are all equal}

Nowadays, society is changing as the way of thinking is. In that sense, there are some human beings who are becoming aware that others should be viewed with no differences. In the case of women, even though there have been many fights when looking for equality, their role as women is still underestimated nowadays which has caused a need to keep teaching generations to transform the way they see women; for instance, in this research study, this first theme is named this way after having discussed as a group and reflecting upon a participant's drawing (Figure 1) where she decided to write a hashtag as a way to title her artwork.

Here, Carolina wanted to express the way she viewed everybody. She mentioned there is nothing that can divide us; therefore, we are all equal no matter our gender or religion as in the end, we all are going to end up in the same place when we die. Likewise, even though she emphasized she viewed herself as a woman, she repeated that she believed we are all equal and for that reason, she wrote some tags people have given to certain patterns in life as a way of representing our ending on earth. Thus, she concluded by explaining she felt she belonged to a new generation, consequently, she personalized her artwork by adding a hashtag.

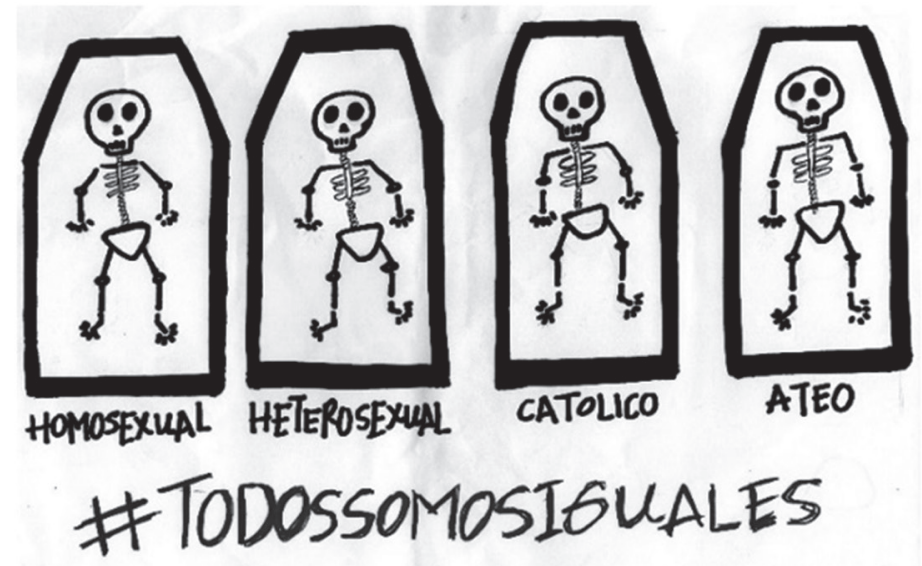

Figure 1. We are all equal. (Carolina, Third moment, Students' artifacts).

After the interpretation of her drawing, participants connected this issue Carolina brought up to the same one the film transmitted to them which was related to the underestimation women have gone through in the past. In this sense, the following examples show how they expressed their thoughts on positing everybody in the same level. 
I consider that there has been an advance, and that is the desire to activate the position of women as equal to men since it is quite necessary and important. I think that right now we could not live without it, I mean, not only men and women in the same condition, but everybody (Jenniwell, Third moment, Third focus group).

In this example, we analyzed Jenniwell's words, not only by means of describing the struggle men / women equality has gone through, but also when believing everybody should be in the same condition. From her perspective, it is seen the way she thinks about people, this fight is not only about men / women, but only every single person who feels in another way. Besides, Jenniwell took us to think about a contrast between generations since she mentioned "I think right now" comparing ways of thinking from previous generations with this current one. In fact, when contrasting her words with her artwork (Figure 2), we could analyze how she made an emphasis on this idea that we are all equal.

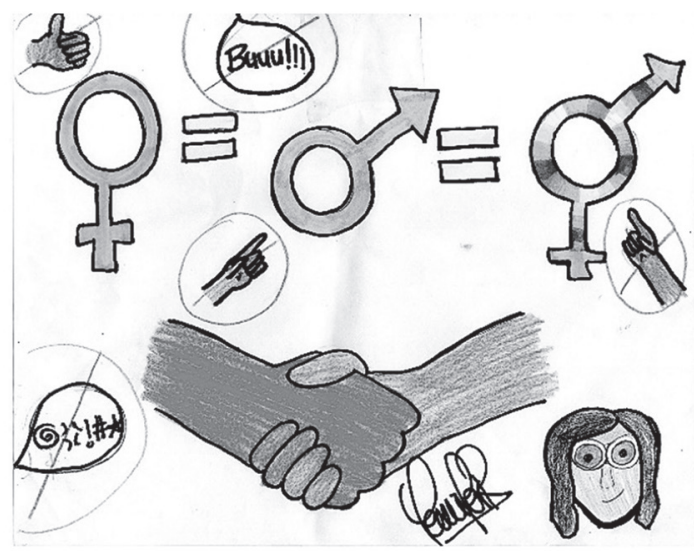

Figure 2. We are all equal. (Jenniwell, Third moment, Students' artifacts).

In this same vein, Figure 3 displays Andrés' artwork which shows his understanding on how equality should be thought out and seen right now. He described his drawing as the way he perceives equality. For him, we all are here not to be judged, but to live happily; that is why, he believes it is not about a certain way to look, dress or feel with our bodies due to equality goes beyond those misconceptions people have been labeled by society.

I think we all should think and see everybody as equal, no matter the way we look, dress or feel with our bodies. We all are here to live happily and that is what I wanted to transmit with my drawing, equality (Andrés, Third moment, Third focus group). 


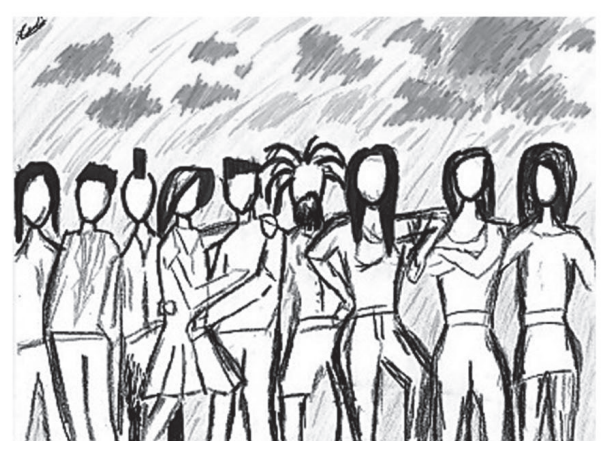

Figure 3. We are all equal. (Andrés, Third moment, Students' artifacts).

Additionally, the following excerpt reflects Daniel's thinking on this same issue. Here, we analyzed how he is conscious about all the fights women have undergone throughout time in order to get the same position as men in society. He as a man, claimed those fights proved to people we are all equal and bearing in mind the big change Ruth, the main character of the film, achieved; she was able to establish an antecedent for future women to cover the fields they can work on. In that sense, men also see equality as only one whole.

All these struggles that are shown here in the film, especially Ruth's, is a great change, because from there, as she says, a precedent was set leaving more space and force for women to be able to cover all the fields they want and so, show us that we are all equal. (Daniel, First moment, First focus group)

Lastly, in this last excerpt, it is interesting to remark how M.F was able to see Ruth as someone who was not interested in fighting for women positioning, but rather for gender equality. She mentioned that there have been some advances regarding that issue and in that sense, women and men are positioned in the same level.

I think that Ruth, having in mind she is a woman, she did not fight only for women but for gender equality. She was looking for that, gender equality! And I feel that right now we have already advanced too much on that (M.F, First moment, First focus group)

\section{Changing roles}

As this new generation of people are going through a new way of thinking, the roles of men and women have gone through a process of changing. In other words, those roles society established for men and women long time ago, have transcended and now people see them from a different perception. In that sense, the following 
examples proved how those roles have been flipped and nowadays, men can perform situations women are "supposed" to do and vice versa.

\section{The role of men.}

This following excerpt shows how the role of men has been changed and accepted over the time with Manuel P's case. He demonstrated men like him from this generation can also perform a duty that a woman was labeled to develop. Specifically, from his narrative, we could analyze that they both, father and mother, spend time with their daughter even though they are not together as a family; they are conscious they both are that girl's parents and they both need to take care of her. Nonetheless, they divide this responsibility equally.

In my case, when I take care of my daughter, I spoil her very much. When my daughter's mother tells me she will party, I am the happiest person because that means I will stay with the girl. Even though I know there are some tasks that are very complex to assimilate for us as men, I do not have a choice but learning how to develop those task by myself (Manuel P, Second moment, Second focus group)

Furthermore, Andrés complements this part of the role of men when narrating he connects the picture he was given in the second moment of this research study with a memory he has from his mother as he was taught in his family (Esen, 2013) but he and his brothers as men could also collaborate doing this house duty.

I relate this picture I was assigned to my mom because she taught us we could also help cleaning the house. She left home to work, and we were in charge of the house, so our brothers and I helped her cleaning (Andrés, Second moment, Second focus group)

In this sense, Cris also contributed by positing himself in showing agreement to Manuel $\mathrm{P}$ and Andrés' way of perceiving their roles as men. Cris in the following excerpt shows how he does not feel less because he does things society has established for women to do at home. In fact, he claims how he feels by performing those house duties and his love for his mother. Here, we could analyze how the role of women influences men's way of thinking. Women become that fundamental piece of the puzzle in men's co-construction as human beings, not just as men.

I love my mother with all my heart, she is the only one who matters to me, that is why I always try to help her with anything she needs. I sweep, mop, clean, cook, wash and I do not really feel I am less because I do that; on the contrary, I feel I contribute in this society by showing men can also help women at home and that does not make us less (Cris, Second moment, Second focus group)

Lastly, Andrea closes our second moment by agreeing with her male classmates on the way they perceive gender equality. She considers that people have changed the 
old perception that "women were made for the family and not for the great struggles of the world" (Quijano, 2001, cited in Calvo, Rendón \& Rojas, 2006, p. 2). Nowadays, this new generation is conscious about gender equality and that is why everybody can do the same things equally. There is nothing impossible when it comes to performing a certain task. In this case in particular, Andrea shows how that wrong perception is left behind since she thinks men have the same skills and capabilities as women to teach children the wrong or good path for them to go. Additionally, we analyzed how both men and women from this new generation show the same thought without complaining about it or showing any type of disagreement. They both position themselves as equal and with the same skills to do anything.

I think that perception that women are the only ones who can do chores and raise children have completely changed today, men also have the same skills and abilities to do it, he can teach his baby the good and bad and not just leave that responsibility to women as it was thought out long time ago (Andrea. Second moment, Second focus group)

\section{The role of women.}

Independency has been marked in women when referring to finding another way for them to live without thinking about labels society has created for them. In the following excerpt, Saluifer narrates how that independency was taught to her throughout her context as she was raised in a countryside. Anything she needed, she was the one who was supposed to get it, everything by herself, without a male figure in her life.

My mom is a single mother, same as the rest of my family, except for an aunt who is married. They all are alone because they are single mothers, with no husband, no male figure at home. I remember that my grandmother always taught us to be independent because I was raised in a countryside, so if I wanted to eat, so I needed to get the firewood, if I wanted to wear clean clothes, I needed to wash them by myself. Thanks to that I am totally independent nowadays (Saluifer, Second moment, Second focus group)

In the same manner, the role of women is evidenced in a way previous generations would not been able to accept. From this participant's intervention, we could analyze the transformation from generation to generation and how those changes have been modified. Machaela positioned herself as a person who is not interested in repeating the same mistakes her previous generations committed. On the contrary, her way of thinking has allowed her to achieve different goals that were not the ones society established time ago for women. She mentioned nowadays those old-time-determined perceptions do not exist and consequently, she positioned herself as someone who looks for learning, studying, traveling, instead of having a family first. 
Personally, I have seen a transformation process in my family that goes from generation to generation and how we have gone through some context changes; for example in the past, it was thought that marriages lasted for many years and that was nice! However, my grandmother lasted many years with my grandfather until he died, but enduring infidelities, beatings and many more things from him just because of her time. Divorcing was frowned upon and condemned. Nowadays, in our time, for our generation, we do not really see that anymore, or well I think at least for me; it is no longer a goal to be a mom, to cook or wash. I want other things for myself; I personally want to learn, study, travel before looking for a family (Machaela, Second moment, Second focus group)

Thus, when contrasting Machaela's words with the artwork (Figure 4) she decided to draw, we could analyze how those words were put into action when describing those new generation plans for her life.

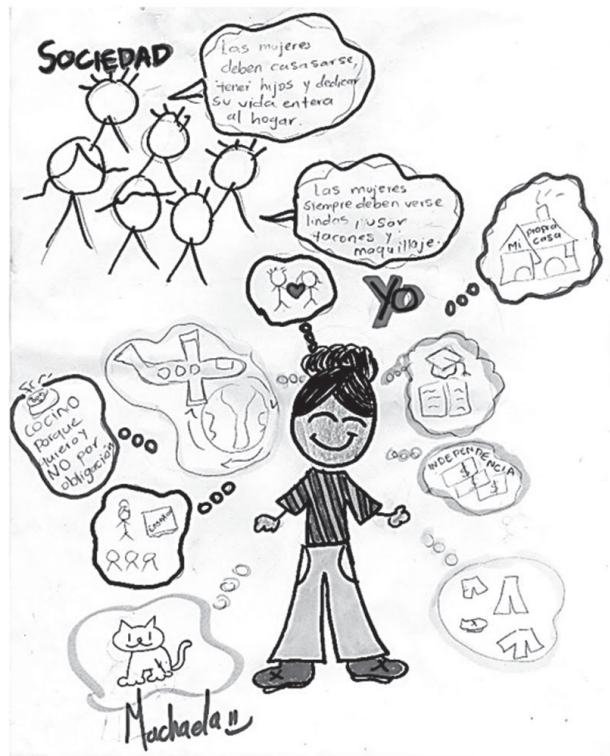

Figure 4. (Machaela, Third moment, Students' artifacts).

Additionally, another perception we could analyze from her is her position regarding independence. She states repeatedly how she sees herself as a woman who will not be depending on any man. In that sense, the way she perceives herself, in terms of living her life, is without a man by her side so far. Her goal nowadays is to enjoy her life first by means of learning, studying, traveling, and afterwards she plans to have someone by her side. Her independence is evidenced by empowering herself when 
believing she can achieve her dreams without the need of a male figure who supports her; in fact, she believes she is strongly able to get what she wants on her own. In that regard, we believe this is exposed thanks to the mark her grandmother and mother left on her when they both experienced dependency on a man in the past.

In the same way, Andrea shows her support to Machaela's way of thinking and she reaffirms she also feels the same way as Machaela. She belongs to a new generation that looks for equality even when finding a person to spend her life with. Based on her narrative, we could analyze that Andrea's words encourage other women to beware of finding someone who supports them at home and does not lean on them as women. They need someone who thinks the same way they do it, otherwise, they will be repeating previous generation's mistakes.

"I reaffirm Machaela's words because I feel the same way. Women do not want to have children or get married yet; we want to enjoy our lives first. We have those mirrors from our families, and we do not want to go back to those old times. In my case, I do not want to repeat those mistakes. I feel that also applies to finding someone in our lives. If we look for a soulmate, we have to beware to know that person will also collaborate at home and will not lean on us" (Andrea, Second moment, Second focus group)

This same thought was compared to Andrea's artwork in the third moment of this research study when she positioned herself as a woman who has different aspirations for her life. Her drawing (Figure 5) shows a division among old ways of thinking from previous generations where women were in charge of everything related to home, and on the other side, new ways of perceiving life which belong to her current generation.

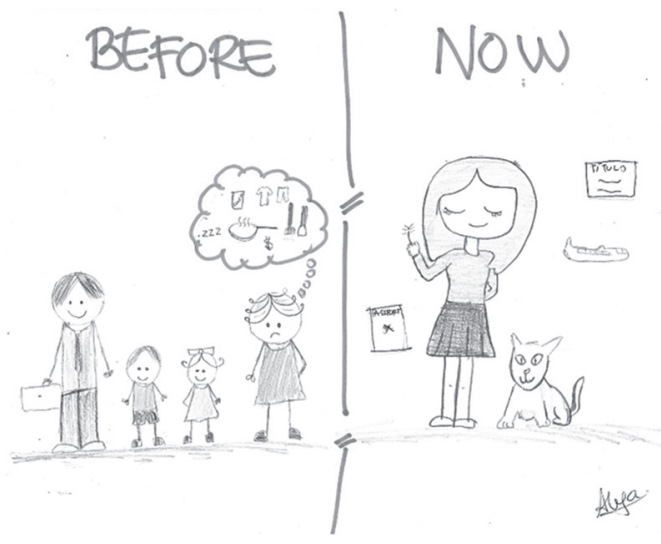

Figure 5. (Andrea, Third moment, Students' artifacts). 


\section{Gender discrimination.}

Even though this new generation has a different way of perceiving equality, there are still people who underestimate woman for differences in relation to their access to education, work, income level (Quintero, 2012). The following example shows how a participant from this research study experienced a situation in which she was not taken into consideration for a job position, just because of her gender, and how another one reflected upon the hiring process a certain Chinese restaurant uses when choosing a waitress.

"I started working as a waitress at a restaurant, and after a month, they were looking for more staff, so I told a male friend to deliver her CV and he got accepted. Like a couple of months later, he earned a promotion as a head waiter just because he was a male. After some time working there, he quit and the vacancy was supposedly for those with more experience, and since I was working before he entered, supposedly I felt that it was my opportunity to advance. However, they promoted a man who had been working there for only two or three months. You see? There are no open doors for us as women and if we want something, we have to give something back, I mean, something sexual and that is not fair" (M.F, Third moment, Third focus group)

In this excerpt, we could analyze how gender discrimination is evidenced when this participant who decided to name herself as (M.F.) was rejected from a job position just because she was a woman. Even though she was told the position was for the one with more experience working in the place, a male was the one who was promoted for the position she thought it was for her. For a second time, she saw how doors she thought were opened to her, turned out to be closed, instead. Gender discrimination happens to be established in this particular case just by the fact of being a woman (Pérez, 2012). M.F evidenced how a male figure had more power when determining this new job position as "power is produced and enacted in and through discourse, relationships, activities, spaces, and times by people as they compete for access to and control to resources, tools, identities" (Birr \& Lewis, 2007, p. 17).

"In my personal experience, let's say that there is a certain preference for men in the kitchen, I mean, in a business. There, he is the cook, the chef, but the woman is not seen as important as a man there, and their payments are not well recognized. On the contrary, they are important at home because they have to cook". (Daniel. Third moment, Third focus group)

In this intervention, Daniel is aware of a sexual division within disciplines where women are stood out or "feminized" for (letters, medicine, human sciences), while men are traditionally "masculinized" for standing out in (mathematics, engineering, law) (Cruz \& Moreno, 2012). Nonetheless, it is key to mention how his words show his new-generation-thinking made him approach an issue that is still present nowadays. 
He mentioned how women are not well seen in the kitchen of a business but rather in the kitchen of their houses. This contradictory perception has underestimated women as objects from home, with no money recognition. On the contrary, men obtain higher salaries regardless of the professional field, the region or the type of institution (public or private) (Barón, 2011, cited in Fuentes, 2012, p. 99).

Lastly, this following lived experience gave us a key issue to address. Luciana mentioned how she thought gender discrimination only took place here or Latin America until she found out how a Chinese restaurant, where she worked, made the hiring process for its waitresses. Gender discrimination is evidenced in this particular case when making some racist comments about the women who were applying for the job. Unfortunately, we only tend to see our local place that we forget about what it is outside this bubble. Thus, we can analyze how gender discrimination takes place anywhere and, in this case, it affected Luciana someway since she realized how those people from that restaurant were also racist when choosing their waitresses.

"When I was working at this Chinese restaurant, I began to learn how they choose waitresses. The wife starts looking at them and saying: this one is black, this one is very skinny, this one is very fat. I thought that this only happened here in Colombia, but they also do it. Gender discrimination is everywhere and in this case from a woman to another woman" (Luciana. Third moment, Third focus group)

\section{Conclusions}

The research study was aimed at unveiling EFL students' perceptions on gender stereotypes through their narratives in three different moments. As a result of it, we noticed how students went on a reflecting process along this research study as it helped them be prepared to act in a professional area (Sööt \& Viskus, 2015) when facing their first classroom experiences (Cote, 2012). Therefore, participants' reflecting processes then emerged as a response to their previous generations' mistakes as they do not want to follow their past generations' steps.

Results showed how participants' lived experiences had an impact on them as they helped them shape their perceptions at a given time in their lives (Lengeling \& Mora, 2016). Thus, their goals are different now and the way they see their future has changed 180 degrees over the time thanks to those gender stereotyped messages they grew up with. That is why, they feel they belong to a different generation, one that thinks and wishes things in a different way.

Additionally, letting their voices be heard through their oral narratives and artwork together was a key part in our research study. We argue that helping EFL students 
express themselves is possible when having artwork as a backup. We evidenced how their artworks contributed to the development of their human consciousness (Read, 1980) as they revealed hidden realities they live in without feeling judged.

Incorporating artwork in the EFL classes contributed to leave footprints in the formation of students' personality at the same time it provided them with the weapons to face a new teaching world (Hernández, Garriga \& Baños, 2009). Based on Peñaloza and Vásquez-Guarnizo (2019), "artwork can help develop observational, thinking, and literacy skills, among many other skills" (p. 133), that is why, it is key to teach visual culture to students, so they can be able to understand their meanings, purposes, relationships, and influences (Freedman, 2003).

\section{Pedagogical implications and further research}

Including artwork in EFL classes becomes an effective tool for teaching and learning (Masoumeh \& Masoud, 2011) as artwork provides students with content to talk about, it involves creative and imaginative contexts and most importantly, art activities increases students' language proficiency (Lee, 2017). Besides, having them as a backup for expressing the way students see things around them result worthy since they can connect lived experiences that lead them to go through a personal reflective process (Núñez \& Téllez, 2015).

Ramos, Aguirre and Hernández (2012) mention that a first step toward promoting intercultural individuals is by encouraging equality in the class. In this sense, we think that it is crucial to start raising awareness about gender stereotypes in future languages teachers, so they get informed and know to handle situations where this issue is presented (Durán, 2006).

In this manner, ELT programs should turn their attention to these types of experiences to incorporate what is being left out, improve teachers' reflection processes, and equip students with the attitudes, skills, and the knowledge to work towards the goal of gender equity in their future teaching contexts (Mojica \& Castañeda-Peña, 2017). That is why, opening spaces such these ones allow EFL students to bring this issue up and avoid seeing it as a taboo. Everything starts when thinking outside the box; thus, we believe that after going through this research study, our field in English teachers' education will be engaged in breaking the gap between addressing gender equality in EFL classroom or continuing being a task for few EFL teachers.

Finally, we think there is a need to break the gap on gender equality. Therefore, we feel that there has to be research on revealing EFL students' identity construction regarding the way they see themselves in the future addressing this important issue within the EFL classroom. 


\section{Annex 1 \\ Universidad Pedagógica y Tecnológica de Colombia \\ Facultad Ciencias De La Educación \\ Escuela de Idiomas \\ Formulario de Consentimiento}

Tunja, 02 de mayo del 2019

Estimad@ estudiante,

El siguiente formulario de consentimiento es para invitarlo a participar en un proyecto de investigación como participante. El objetivo principal de esta propuesta de investigación es conocer qué percepciones revelan los estudiantes de Idiomas Modernos/ Lenguas Extranjeros sobre los estereotipos de género a través de sus narrativas. Por lo tanto, para el propósito de este estudio, su participación es de vital importancia y completamente voluntaria. Consecuentemente, no habrá compensación financiera ni académica por ser parte de ella, teniendo la posibilidad de retirarse cuando sienta que lo desea.

Además, me gustaría hacerle saber que su nombre real no se mencionará en el estudio como tal, por el contrario, tendrá la oportunidad de crear su propio seudónimo. Los instrumentos que se utilizarán en esta investigación serán los artefactos por parte de los estudiantes, diarios de campo por parte del docente y discusiones en grupos focales al final. Especificamente, los estudiantes pasarán por tres momentos durante esta investigación en los que reflexionarán sobre los estereotipos de género a través de una película, sus propias obras de arte y la de otros dentro de su propio contexto.

Adicional, el manejo ético y la confidencialidad de la información están suscritas a las normas constitucionales y legales colombianas relacionadas con los datos personales y los derechos de autor. Por último, los resultados de este estudio se utilizarán únicamente para preparar informes académicos, presentar trabajos en eventos académicos y preparar artículos o libros de naturaleza cientifica en el futuro. Finalmente, este estudio no traerá ningún prejuicio para usted como participante, ya que, por el contrario, se espera que revele cuales son las percepciones que los estudiantes de Idiomas Modernos/ Lenguas Extranjeros tienen sobre los estereotipos de género a través de sus narrativas.

Por favor, no firme este formulario de consentimiento hasta que todas sus preguntas hayan sido resueltas. Si acepta participar, autorice este documento firmándolo con su nombre completo.

Firma:

Seudónimo: Andrea

iMuchas gracias por su participación!

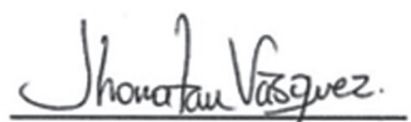

Jhonatan Vásquez-Guarnizo Docente de inglés

ihonatan.vasquez@uptc.edu.co +573187932775
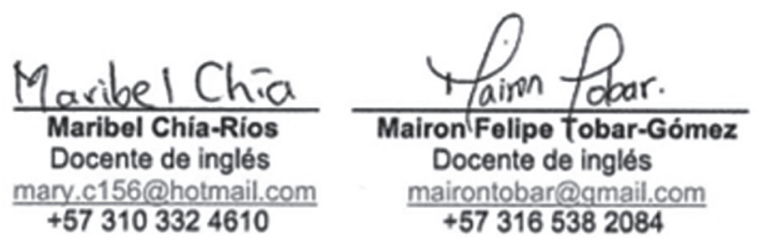


\section{References}

Aguirre Morales, J., \& Ramos Holguín, B. (2011). Fostering skills to enhance critical educators: A pedagogical proposal for pre-service teachers. HOW Journal, 18(1), 169-197.

Andrews, M., Squire, C., \& Tamboukou, M. (2013). Doing narrative research. London: Sage.

Barber, S. (2015). Using art to teach critical thinking. https://www.edutopia.org/ discussion/using-art-teach-critical-thinking

Barrera, M. \& Cantor, S. (2007). Socio-cultural stereotypes: Exploring students' perceptions regarding social issues. HOW Journal, 14, 161-173.

Bell, J. (1993). Doing your research project: A guide for first- time researchers in Education and Social Science. Open University Press.

Birr, M. \& Lewis, C. (2007). Examining opportunities to learn literacy: The role of critical sociocultural literacy research. In Lewis, C., Enciso, P., \& Birr, E. (Eds). Reframing sociocultural research on literacy: Identity, agency and power, 15-48. Routledge.

Brown, S. (2010). Popular films in the EFL classroom: Study of methodology. Procedia Social and Behavioural Sciences, 3, 45-54.

Bruner, J. (1994). Life as narrative. In Dyson, A. \& Genishi, C. (Eds.), The need for story: Cultural diversity in classroom and community, 28-37. Urbana, IL: National Council of Teachers of English.

Calvo, G., Rendón, D., \& Rojas, L. I. (2006). Formación y perfeccionamiento docente desde la equidad de género. http://www.oei.es/docentes/articulos/formacion perfeccionamiento_docente_equidad_genero.pdf

Castañeda, A. (2012). EFL women-learners' construction of the discourse of egalitarianism and knowledge in online-talk-in-interaction. Colombian Applied Linguistics Journal, 14(1), 163-179.

Castañeda-Peña, H. (2008a). 'I said it!' 'I'm first!': Gender and language-learner identities. Colombian Applied Linguistic Journal, 10, 112-125.

Castañeda-Peña, H. (2008b). Positioning masculinity and femininity in preschool EFL education. Signo y Pensamiento, 27(53), 314-326.

Castañeda-Peña, H. (2009). Masculinities and femininities go to preschool: Gender positioning in discourse. Editorial Pontificia Universidad Javeriana. 
Castañeda-Peña, H. (2010). The next teacher is going to be...Tereza Rico: Exploring gender positioning in an all-girl preschool classroom. Magis, Revista Internacional de Investigación en Educación, 3(5), 107-124.

Corral, Y. (2014). Introducing Gender Stereotypes in the EFL Classroom. [Master's thesis, Universidad de Jaén] Master's in Applied Linguistics to Teaching English as a Foreign Language. http://tauja.ujaen.es/bitstream/10953.1/2237/1/1314YCorral FP.pdf

Cote, G. (2012). The role of reflection during the first teaching experience of foreign language pre-service teachers: An exploratory-case study. Colombian Applied Linguistics Journal, 14 (2), 24-34.

Coulter, C., Charles, M., \& Poynor, L. (2007). Storytelling as pedagogy: An unexpected outcome of Narrative Inquiry. Curriculum Inquiry, 37(2), 103-122.

Cruz, J. \& Moreno, E. (2012). Educación superior mercado laboral: Reflexiones sobre la reproducción de la dominación sexual. Educar en la Equidad: Boletina Anual, 2, 48-63.

Denscombe, M. (2007). The good research guide for small-scale social research projects (3rd ed.). McGraw-Hill.

Durán, N. (2006). Exploring gender differences in the EFL classroom. Colombian Applied Linguistics Journal, 8, 123-136.

Eagly, A. \& Karau, S. (2002) Role congruity theory of prejudice toward female leaders. Psychological Review, 109(3), 573-598.

Efron, S., \& Ravid, R. (2013). Action research in education: A practical guide. Guilford Press.

Esen, Y. (2013). Making room for gender sensitivity in pre-service teacher education. European Researcher, 61(10-2), 2544-2554. https://doi.org/10.13187/ er.2013.61.2544

Fiske, S. (1993). Social cognition and social perception. Annual Review of Psychology, 44, 155-194.

Freedman, K. (2003). Recent shifts in US art education. In Addison, Nicholas and Burgess, Lesley (eds.). Issues in Art and Design Teaching. RoutledgeFalmer, Oxon.

Fuentes, L. (2012). Hacia la equidad de género en la educación superior: Una interpelación a las políticas educativas. Educar en la Equidad: Boletina Anual, 2, 94-104.

Gadamer, H. (2002). Acotaciones hermenéuticas. Editorial Trotta. 
Gardner, R. (1985). The Attitude/Motivation Test Battery: Technical Report. http:// publish.uwo.ca/ gardner/docs/AMTBmanual.pdf

Haque, M., \& Chandran, S. (2004). Discourse of gender: Conflicting ideologies vs. social policies. BRAC University Journal, 1(2), 21-32.

Hernández, I., Garriga, M. \& Baños, I. (2009). El papel del arte y sus manifestaciones en la enseñanza de lenguas: Reflexiones y experiencias. Didáctica. Lengua y Literatura, 21, 191-202.

Hopkins, D. (2008). A teacher's guide to classroom research (2nd ed.). Cambridge University Press

Ifegbesan, A. (2010). Gender-stereotypes belief and practices in the classroom: The Nigerian post-primary school teachers. Global Journal of Human Social Science, 10(4), 29-38.

Lankshear, C., \& Knobel, M. (2004). A handbook for teacher research: From design to implementation. Open University Press

Lee, S. (2017). Teaching English through Art. www.gendaieigo.info/.../20171115 Teaching-English-Through-

Lengeling, M. M., \& Mora Pablo, I. (2016). Reflections on critical incidents of EFL teachers during career entry in Central Mexico. HOW, 23(2), 75-88.

Martin, C. \& Halverson, C. (1981). A schematic processing model of sex-typing and stereotyping in children. Child Development, 52, 1119-1134.

Masoumeh, F. \& Masoud, H. (2011). The impact/s of using art in English language learning classes. Procedia - Social and Behavioral Sciences, 31, 923-926.

Mojica, C. P., \& Castañeda-Peña, H. (2017). A learning experience of the gender perspective in English teaching contexts. PROFILE, 19(1), 139-153.

Núñez, A., \& Téllez, M. (2015). Reflection on teachers' personal and professional growth through a materials development seminar. HOW Journal, 22(2), 54-74.

Ormrod, J. E. (2005). Using student and teacher artifacts as case studies in educational psychology. The Clearing House, 78(5), 213-217.

Peñaloza, A. C., \& Vásquez-Guarnizo, J. (2019). Reflections on educational issues among modern language students. HOW Journal, 26(1), 129-151.

Pérez, A. (2012). Género y educación superior: Más allá de lo obvio. Educar en la Equidad: Boletina Anual, 2, 64-75. 
Quintero, Ó. (2012). Discriminaciones raciales cotidianas como forma de construcción de masculinidades en la universidad. Educar en la Equidad: Boletina Anual, 2, 26-33.

Rabiee, F. (2004). Focus-group interview and data analysis. Proceedings of the Nutrition Society 63, 655-660.

Ramos Holguín, B., Aguirre Morales, J., \& Hernández, C. M. (2012). A pedagogical experience to delve into students' sense of cultural belonging and intercultural understanding in a rural school. HOW Journal, 19(1), 123-145.

Read, H. (1980). Imagen e idea, FCE.

Richards, K. (2000). Trends in qualitative research in language teaching since 2002. Language Teaching, 42(2), 147-180.

Riessman, C. (2005). Narrative Analysis. In: Narrative, memory \& everyday life. University of Huddersfield, Huddersfield. http://eprints.hud.ac.uk/id/eprint/4920/

Rojas, M. (2012). Female EFL teachers: Shifting and multiple gender and languagelearner identities. Colombian Applied Linguistics Journal, 14(1), 92-107.

Schäffler, A. (2018). Applying advanced methods of reflective practice in decisionmaking. In S. Stigler. Stimulating Reflection when Using Artworks from the Collection: DIAL for Complex Artworks.

Schander, C., Balma, B, \& Massa, A. (2013). The joy of art in the EFL classroom. European Scientific Journal, 9(2), 409-414.

Şeker, M. \& Dinçer, A. (2014). An analysis of gender stereotyping in English teaching course books. Faculty of Education Journal, 43(1), 90-98.

Sikes, P., \& Gale, K. (2006). Narrative approaches to educational research: Research in education. http://www.edu.plymouth.ac.uk/resined/narrative/narrativehome.htm

Six, B. \& Eckes, T. (1991). A closer look at the complex structure of gender stereotypes. Sex Roles: A Journal of Research, 24, 57-71.

Sööt, A \& Viskus, E. (2015). Reflection on teaching: A way to learn from practice. Procedia - Social and Behavioral Sciences, 191, 1941-1946.

Stangor, C., \& Lange, I. (1994). Mental representations of social groups: Advances in understanding stereotypes and stereotyping. Advances in Experimental Social Psychology, 26, 357-416.

Torres-Cepeda, N., \& Ramos-Holguín, B. (2019). Becoming language teachers: Exploring student-teachers' identities construction through narratives. GiST Journal, 18, 6-27. 
Trahar, S. (2006). Narrative research on learning, comparative and international perspectives. Symposium Books Ltd.

Weber, S. \& Mitchell, C. (1996). Drawing ourselves into teaching: Studying the images that shape and distort teacher education. Teaching and Teacher Education, 12(3), 303-313.

Wright, S. (2004). Perceptions and stereotypes of ESL students. The Internet TESL Journal, 10(2). http://iteslj.org/Articles/Wright-Stereotyping.html

\section{Authors}

*Jhonatan Vásquez-Guarnizo holds an M.A in Language Teaching from Universidad Pedagógica y Tecnológica de Colombia and a B.A in English Language Teaching from Universidad de la Amazonia. He is currently a researcher and a fulltime English language professor in the School of Languages at UPTC. He is also part of the research group "TONGUE" and a first-semester student in the master's in Education at Universidad Externado de Colombia.

ORCID: https://orcid.org/0000-0002-0630-6321

Maribel Chía-Ríos holds a B.A. in Modern Languages from Universidad Pedagógica y Tecnológica de Colombia (UPTC). She currently works at Institución Educativa Luis Maria Jimenez in Aguazul, Casanare where she teaches Spanish/English, besides studying her last semester in the Master's in Language Teaching at the UPTC.

ORCID: https://orcid.org/0000-0002-2520-7863

Mairon Felipe Tobar-Gómez holds a B.A in English Language Teaching from Universidad de la Amazonia. He currently works at Colegio San Viator in Tunja, Boyacá where he teaches English to tenth and eleventh graders, besides studying his Master's in Languages Didactic at Universidad de la Salle.

ORCID: https://orcid.org/0000-0003-2905-4670

How to reference this article: Vásquez-Guarnizo, J., Chía-Ríos, M., \& Tobar-Gómez, M. F. (2020). EFL Students'perceptions on Gender Stereotypes. GIST - Education and Learning Research Journal, 21, 141-166. https://doi.org/10.26817/16925777.836 